\title{
METODOLOGI ILMU: \\ Dari Teori Hingga Teologi
}

\author{
Mohammad Muslih \\ ISID Gontor Ponorogo \\ mmuslih@yahoo.com
}

\begin{abstract}
Abstrak
Tulisan ini merupakan review dari buku Science and Religion: a Critical Survey karya Holmes Rolston, khususnya bab pertama yang berjudul "Methods in Scientific and Religious Inquiry". Bab pertama ini, secara umum, menguraikan pendekatan atau kawasan kajian Rolston dalam melihat kemungkinan pertemuan antara sains dan agama. Dalam penglihatan Rolston, antara teori dalam sains dan teologi dalam agama lebih banyak memiliki kesamaan dari pada perbedaannya. "...dalam bentuk logika umum sains dan agama, lebih memiliki kesamaan dari pada yang sering diduga...", demikian Rolston. Rolston mengakui bahwa pandangannya itu membawa implikasi terhadap pandangan positivisme dan saintisme yang selama ini mengagungkan sains dan merendahkan agama. Bagi Rolston, pandangan itu jelas "mengandung kesalahpahaman serius tentang alam, baik dari metode ilmiah maupun metode keagamaan".
\end{abstract}

\begin{abstract}
SCIENTIFIC METHODOLOGY: FROM THEORY TO THEOLOGY. This paper is a review of the book entitled "Science and Religion: A Critical Survey" written by Holmes Rolston, especially of the first chapter entitled "Methods in Scientific and Religious Inquiry." The first chapter outlines the approach of Rolston's work in viewing the possibility of drawing together science and religion. According to Rolston, theories in science and theology in religions have more in common than differences. He claims "... in the form of general logic of science and religion, had more in common than is often thought to ...". Rolston admitted that his view may carry implications for positivism and scientism that during this glorify science and degrade religion. for Rolston, the view was clearly "contains a serious misunderstanding about the nature, both from the perpectives of science and religion as well".
\end{abstract}

Kata Kunci :Teori, Teologi, Metode 


\section{A. Pendahuluan}

Rolston memulai uraiannya dengan berbicara soal dinamika dan perkembangan suatu teori. Pertanyaan pokok yang berusaha ia jawab di sini adalah, bagaimana suatu teori dan juga teologi itu dirumuskan. Menurutnya, rahasia filosofis di balik perkembangan teori adalah apa yang ia sebut dengan logika hipotetik-deduktif. ${ }^{1}$ Dengan logika ini, fakta, bahkan realitas representasikan dengan berlandaskan teori tertentu atau lebih tepatnya hipotesa tertentu. Artinya dunia sebagaimana diketahui manusia (ilmuwan dan Agamawan?) merupakan hasil deduksi dari suatu teori. Dengan begitu, validitas pengetahuan (dan juga teologi) tergantung dengan kesahihan teori yang digunakan. Inilah makna logika hipotetik, logika bersyarat, yang disebut Rolston dengan pola pikir "jika-maka".

Sebagaimana terlihat pada tema-tema yang dibahas, tampak jelas bahwa "metode" dalam pengertian Rolston sebenarnya lebih sebagai logic of Discovery yang bersifat filosofis dari pada sebagai process and procedure yang bersifat teknis. Artinya, survey kritis Rolston mengambil kawasan "basis filosofis ilmu" yang menjadi dasar tumbuh kembangnya teori dan juga tumbuh kembangnya teologi. Ada empat tema yang menjadi fokus uraian Rolston yaitu (1) Teori, keyakinan, dan pengalaman; (2) Model, pola, dan paradigma; (3) objektivitas dan keterlibatan, dan (4) logika ilmiah dan agama. Dengan empat tema tersebut ada beberapa isu pokok yang menjadi perhatian Rolston yang akan diuraikan di bawah ini.

\section{B. Logika Hipotetis-Deduktis: Tumbuh kembanganya Teori dan Teologi}

Menurut Rolston, pembentukan teori dalam sains maupun teologi dalam agama sama-sama berjalan di atas logika hipotetisdeduktis. Hanya saja berbeda dalam proses deduksinya. Jika dalam sains deduksi itu dilakukan dengan observasi dan eksperimen, sementara dalam agama/ deduksi itu dilakukan dengan jalan

${ }^{1}$ Holmes Rolston III, Science and Religion: a Critical Survey, (USA: Templeton Foundation Press, 2006), h. 2. 
eksperien. ${ }^{2}$ Konsekuensi logis dari pandangan ini adalah proses pengamatan (observasi dan eksperimen) dan pengalaman (experience) tidak pernah sedemikian otonom atau netral, tetapi pasti selalu dalam "terang" teori atau asumsi tertentu.

Terkait dengan pengembangan teori, proses deduksi dapat berbentuk "verifikasi" sebagaimana ditawarkan kelompok Positivisme Logis $^{3}$ yang juga diakui Rolston, dan dapat juga berbentuk falsifikasi (error elimination) sebagaimana ditawarkan Karl Popper. ${ }^{4}$ Prinsip verifikasi atau konfirmasi mengatakan bahwa suatu teori terbangun atau mengalami perkembangan jika ditemukan fakta-fakta yang mendukung. Maka proses observasi, eksperimen-eksperimen diarahkan untuk terjadinya akumulasi bukti.

Sebaliknya, prinsip falsifikasi mengatakan bahwa teori bisa terjadi atau dikatakan berkembang jika ada upaya serius untuk menggugurkannya. Selama suatu teori bisa bertahan dalam upaya falsifikasi, selama itu pula teori tersebut tetap kokoh, meski ciri kesementaraannya tetap tidak hilang. ${ }^{5}$ Suatu teori bersifat ilmiah, jika terdapat kemungkinan secara prinsipil untuk menyatakan salahnya. Itulah maksud dari "prinsip falsafi-abilitas". Suatu teori yang secara prinsipil mengeksklusikan setiap kemungkinan untuk mengemukakan suatu fakta yang menyatakan salahnya teori itu, menurut Popper, pasti tidak bersifat ilmiah.

Atas dasar pemikiran ini, proses deduksi akan menimbulkan dua kemungkinan. Pertama, pengamatan dan pengalaman akan 'diperjuangkan' untuk membuktikan (kebenaran) suatu teori atau

${ }^{2}$ Ibid., h. 4.

${ }^{3}$ Prinsip verifikasi ini menyatakan bahwa suatu proposisi adalah bermakna (meaningful) jika ia dapat diuji dengan pengalaman dan dapat diverifikasi dengan pengamatan (observasi). Rudolf Camap,"Protocol Statements and Formal Mode of Speech", dalam Oswald Hanfling (ed.), Essential Reading in Logical Positivism, (Oxford: Basil Blackwell, 1981), h. 152

${ }^{4}$ Pemikiran Popper inilah yang mengantarkannya dikenal sebagai epistemologi lalisme-kritis dan empirisis modern. Karl R. Popper, Conjuctures and Refutations: The Growth litific Knowledge, ed. Revisi, cet. V, (London: Routledge, 1974), h. 52

${ }^{5}$ R. Henre, “ History of Philosophy of Science”, dalam Paul Edward (ed.). The Encyclopedia of Phylosophy, vol. VI, (289-2), h. 294 
asumsi. ${ }^{6}$ Artinya fakta harus tunduk pada teori. Dan kemungkinan kedua, suatu teori justru akan gugur digantikan oleh teori yang baru, jika dengan proses verifikasi dan falsifikasi ditemukan fakta baru yang bertentangan.

Demikian ini terjadi, tidak hanya pada sains, tetapi juga pada agama. Dalam arti, pengalaman keagamaan difungsikan sebagai batu ujian bagi dogma. ${ }^{7}$ Rolston menunjukkan beberapa contoh keyakinan teologis yang masih terus bertahan karena dukungan pengalaman, juga beberapa contoh yang menunjukkan adanya perubahan keyakinan karena pengalaman berkata lain. Hanya saja dalam tulisannya itu, Rolston seakan ingin mengatakan bahwa pada kenyataannya sebagian besar dogma agama yang ada di dunia mengalami perubahan seiring dengan pengalaman pemeluknya.

\section{Paradigma: Jatuh-Bangunnya Teori dan Teologi}

Terkait dengan uraian sebelumnya; tentang teori, setiap teori memiliki "kerangka dasar" atau yang sering disebut dengan theoretical framework. Berbeda teori berbeda pula kerangkanya. Inilah 'rahasianya' mengapa satu objek kajian yang sama bisa dihasilkan kesimpulan (teori) yang berbeda, karena teori yang digunakan memang berbeda. Aplikasinya dalam kerja ilmiah, setiap theoretikal framework menyediakan logic of discovery-nya yang khas. Kekhasan kerangka dasar dari teori tertentu itulah yang dimaksud Rolston sebagai "model”.

Dengan demikian suatu teori tertentu berkonsekuensi pada model atau desain kerja ilmiah tertentu. Namun, dapat juga suatu teori mengalami eskalasi sedemikian rupa, sehingga menjadi sangat dominan, karena memberikan konteks yang lebih luas bagi teka-teki keilmuan serta memberikan ruang bagi penyelesaian banyak problem ilmiah. Di sinilah suatu teori berubah status menjadi paradigma. Rolston menulis: "Paradigma adalah model dominan, yang dalam beberapa lingkup pengalaman yang agak luas, menentukan konteks penjelasan dan kejelasan". ${ }^{8}$

\footnotetext{
${ }^{6}$ Rolston, Science..., h. 9.

${ }^{7}$ Ibid., h. 10.

${ }^{8}$ Ibid., h. 12.
} 
Di sini nampak bahwa Rolston mengikuti Thomas S. Kuhn yang melihat kerja ilmiah pada 'kawasan' yang lebih luas. Jika kelompok Lingkaran Wina dan Popper melihat peran teori pada kerja ilmiah, Kuhn malah meletakkan teori pada posisi yang sangat tergantung dengan paradigmanya. Menurut Kuhn, paradigma keilmuan berfungsi sebagai (a) A set of assumption and (b) beliefs concerning, yaitu asumsi yang "dianggap" benar. ${ }^{9}$ Untuk dapat sampai pada asumsi itu harus ada perlakuan empirik yang tidak terbantahkan. Paradigma itu bersifat filosofis yang mendapat dukungan dari sejumlah teori yang bernaung di bawahnya. Untuk ini Rolston menulis: "sebuah paradigma adalah matrik disipliner dan juga merupakan sudut pandang teoretis". ${ }^{10}$

Peran paradigma dapat dikatakan sebagai a mental window, tempat terdapat "frame" yang dipakai oleh masyarakat pendukungnya untuk memecahkan teka-teki (puzzle solve) keilmuan yang dihadapi. "Paradigma yang baik mempunyai karakter seperti 'peta' sehingga realitas dapat digambarkan semacam gambar dasar”, demikian Rolston menjelaskan. ${ }^{11}$ Fungsi peta itu mengorganisir realitas ia tidak pernah menjadi wadah yang pasif, tetapi sebaliknya selalu aktif membantu menemukan organisasi realitas dan mengintisarikan struktur - strukturnya. ${ }^{12}$

Menurut Kuhn, ${ }^{13}$ kerja komunitas ilmiah tidak pernah bisa keluar dari "kepercayaan filosofis" yang ia sebut dengan paradigma. Berdasarkan penelusuran historisnya atas sains, Kuhn berhasil membuktikan bahwa perkembangan ilmu bukan karena akumulasi bukti sebagaimana prinsip verifikasi Positivisme Logis atau gugurnya teori dalam falsifikasi Popperian dengan prinsip error elimination, tetapi karena revolusi ilmiah dengan terjadinya shifting paradigm. Revolusi ilmiah terjadi melalui beberapa tahapan, yaitu: tahap normal, anomali, krisis, dan shifting paradigm.

Tahap pertama, paradigma ilmu membimbing dan

${ }^{9}$ Agus Salim, Teori-Teori dan Paradigma Penelitian Sosial, (Yogyakarta: Tiara Wacana, 2001), h. 42

${ }^{10}$ Ibid., h. 13.

${ }^{11}$ Ibid., h. 14.

${ }^{12}$ Ibid.,

${ }^{13}$ Thomas S. Kuhn, The Structure of Scientific Revolution, (Chicago: The University of 50 Press, 1970). 
mengarahkan aktivitas ilmiah dalam masa ilmu normal (normal science). Di sini para ilmuwan berkesempatan menjabarkan dan mengembangkan paradigma sebagai model ilmiahyang digelutinya secara rinci dan mendalam. Dalam tahap ini para ilmuwan tidak bersikap kritis terhadap paradigma yang membimbing aktivitas ilmiahnya.

Tahap kedua ketika, dalam aktivitas ilmiahnya, para ilmuwan menjumpai berbagai fenomena yang tidak dapat diterangkan dengan paradigma yang digunakan sebagai bimbingan atau arahan aktivitas ilmiahnya itu, ini dinamakan anomali. Anomali adalah suatu keadaan yang memperlihatkan adanya ketidakcocokan antara kenyataan (fenomena) dengan paradigma yang dipakai.

Tahap ketiga, menumpuknya anomali menimbulkan krisis kepercayaan dari para ilmuwan terhadap paradigma. Paradigma mulai diperiksa dan dipertanyakan. Para ilmuwan mulai keluar dari jalur ilmu normal. Tahap keempat, para ilmuwan bisa kembali lagi pada cara-cara ilmiah yang lama sembari memperluas dan mengembangkan suatu paradigma tandingan yang dipandang bisa memecahkan masalah dan membimbing aktivitas ilmiah berikutnya. Proses peralihan dari paradigma lama ke paradigma baru inilah yang dinamakan revolusi ilmiah.

Sama seperti Kuhn, Rolston juga mengakui bahwa paradigma merupakan konstruksi sosial dari komunitas ilmiah (scientific community). Karena itu, tidak jarang para penganutnya mempertahankannya dengan menggunakannya untuk menafsirkan pengalaman baru atau dengan memperkenalkan hipotesishipotesis tambahan jika terdapat pengalaman yang tidak sesuai. ${ }^{14}$ Kuhn memang menggunakan model politik dalam menjelaskan perkembangan sains. Kuhn memakai istilah revolusi untuk menggambarkan proses invensi (invention) dalam sains dan memberi penekanan serius pada aspek wacana ilmiah. Bagi Kuhn, revolusi ilmiah dan revolusi politik memiliki karakter yang sama keduanya terbentuk dari persepsi yang ada di masyarakat.

Karena sifatnya yang demikian ini, kemudian dikenal ada

${ }^{14}$ Rolston, Science..., h. 13. 
paradigma dominan dan paradigma 'pinggiran', ada paradigma koordinat dan ada paradigma subordinat, ada paradigma mayor dan ada paradigma minor, ada paradigma mainstream dan ada paradigma heretis. Artinya munculnya dua "kategori" paradigma semacam itu lebih bersifat sosiologis ketimbang bersifat saintificlogic

Rolston menyebut contoh tentang paradigma dominan atau subordinat pada sains, misalnya astronomi Copemican dan Ptolemaic; ketetapan spedes dan evolusi spedes; ruang waktu absolut Newton dan relativitas Einstein; mekanisme dan teleologi; determinisme dan indeterminisme; seleksi alam dan orthogenesis; teori-teori phlogiston dan teori-teori ether; tingkatan taksonomi dari filum, kelas, ordo, familia, genus, dan species; uniformitarianisme dan katastropisme geologic; periode Paleozoikum. Mesozoikum, dan Cenozoikum; teori-teori gelombang dan panikel cahaya; teori atom. ${ }^{15}$

Bagi Rolston, segala karakteristik paradigma keilmuan ini juga terjadi pada agama. Paradigma agama ditemukan secara jelas di dalam penegasan-penegasan keyakinan, misalnya, bahwa Yesus Kristus adalah manusia seutuhnya, tuhan seutuhnya, satu orang; bahwa Tuhan adalah cinta kasih; bahwa orang-orang diciptakan di dalam bayangan Tuhan (karakter tuhan pada diri seseorang); bahwa suatu jiwa yang kekal tinggal di dalam tubuh; bahwa Tuhan menakdirkan semua: bahwa bangsa Israel adalah bangsa yang terpilihnya; bahwa Tuhan (Allah) ada, dan Muhammad adalah utusan-Nya; bahwa atman (batin diri) adalah Brahma, Kemutlakan tuhan; bahwa dunia yang konvensional (samsara) tidak nyata (maya); bahwa dunia biasa (samsara) adalah dunia transmundane (nirvana) tempat terjadinya pencerahan; dan bahwa tanpa pencerahan tersebut sebuah hukum sebab akibat (karma) berlaku bila mana orang-orang bereinkarnasi dari kehidupan yang satu ke kehidupan yang lain.

Sebuah paradigma bukan hanya kognitif tetapi membawa semacam keterampilan untukmemutuskan, beberapa pengetahuan implisit tentang bagaimana menggunakan hasilnya. Beberapa

${ }^{15}$ Ibid. 
contoh paradigma agama yang telah ditinggalkan sepenuhnya atau dipertanyakan secara serius oleh masyarakat modern meliputi animisme dan politheisme, pendapatan enam hari, diturunkannya suami istri pertama dan transmisi biologis berikutnya setelah dosa awal tersebut, teori penyakit yang dimiliki setan, cerita tiga alam semesta (surga di atas, bumi, neraka di bawah), penjelasan tentang penyudahan dosa dan toleransi pada zaman pertengahan, dan (banyak yang direvisi jika tidak ditinggalkan)/ kebenaran verbal Bible. ${ }^{16}$

Rolston menambahkan satu lagi sifat paradigma, yakni soal kecenderungan paradigma menjadi semacam ideologi yang secara arogan diterapkan untuk membaca fenomena apapun, kapanpun, dan di manapun. Untuk ini Rolston menyebutnya dengan "blik", yaitu teori yang berkembang arogan, yang terlalu sulit untuk ditaklukkan oleh pengalaman. ${ }^{17} \mathrm{Di}$ sini telah terjadi semacam universalisasi norma, bahkan menjadi totalitarianisme. "Arogansi" paradigma keilmuan semacam itu, oleh Kuhn disebut dengan Incommensurable yaitu suatu gambaran dari paradigmaparadigma yang terus berkompetisi dalam sains dan cenderung menegaskan lawan-lawannya. ${ }^{18}$ Hal demikian tampaknya terjadi juga pada tradisi keagamaan, seperti ada truth claim, yang juga menegaskan yang lain.

\section{Gugurnya Klaim Objektivitas}

Isu ketiga yang diangkat Rolston adalah soal riwayat disintegrasi antara sains dan agama yang - menurutnya - lebih terkait dengan klaim-klaim sains yang sebenarnya tidak proporsional. Sebagaimana diketahui, beberapa sumber menyebutkan, tidak kurang dari 400 tahun, dunia keilmuan telah berada dalam dominasi otoritas paradigma positivisme, tidak hanya dalam ilmu alam tetapi juga pada ilmu-ilmu sosial, bahkan ilmu humanities. Seiring dengan proses universalisasi norma dan paradigma tersebut, temuan-temuan sains mengalami eskalasi (escalation) menjadi apa yang disebut Lyotard sebagai

\footnotetext{
${ }^{16}$ Ibid., h. 14.

${ }^{17}$ Ibid., h. 16.

${ }^{18}$ Kuhn, The Structure..., h. 150
} 
grand narrative ${ }^{19}$ yang mematikan narasi-narasi kecil dan menjadi kekuatan kuasa yang memarginalkan apa saja yang dianggap tidak rasional sebagaimana diungkap Foucault. ${ }^{20}$

Lahirnya norma-norma ilmiah sebagai garis demarkasi antara yang ilmiah dan non-ilmiah, bisa dikatakan sebagai buah dari icfleksi filsafat positivisme. Auguste Comte, sang pelopor positivisme/ hanya mempercayai fakta positif ${ }^{21}$ yang digali dengan metodologi ilmiah. Lalu dilanjutkan oleh para filsuf Lingkaran Wina yang mengajukan prinsip verifikasi untuk membedakan bahasa yang meaningfull dan meaningless, juga Karl Popper yang menawarkan falsifikasi (error elimination) sebagai standar ilmiah. ${ }^{22}$

Konsekuensi pandangan ini, membuat keilmuan modern menganut tiga prinsip: bersifat empiris-objektif, deduktifnomologis, instrumental-bebas nilai. Ketiga prinsip positivistis ini, menurut Anthony Giddens, membawa implikasi sebagai berikut. Pertama, prosedur-prosedur metodologis ilmu-ilmu alam dapat langsung diterapkan pada ilmu-ilmu sosial. Dengan cara ini, objek observasi ilmu-ilmu sosial disejajarkan dengan dunia alamiah. Kedua, hasil-hasil riset dapat dirumuskan dalam bentuk 'hukumhukum' seperti dalam ilmu-ilmu alam. Dan ketiga, ilmu-ilmu sosial itu harus bersifat teknis, yaitu menyediakan pengetahuan yang bersifat instrumental murni. Pengetahuan itu harus dapat dipakai untuk keperluan apa saja sehingga tidak bersifat etis dan juga tidak terkait pada dimensi politis. Artinya, seperti ilmu-ilmu

${ }^{19}$ Lyotard. The Postmodern Condition, A Report and Knowledge, (Manchester: Manchester University Press, 1984), h. 37

${ }^{20}$ Michel Faucoult, Diciplin and Punish: Tfie Brith of Prison, trans. Alan Sheridan, (New York: Peregrine, 1979); Bandingkan dengan Budi Hardiman, "Kritik atas Patologi Modernitas dan [post] Modernisme: Habermas dan Para Ahli Waris Ncitzschc" dalam Driyarkara, Tahun XIX, No. 2.

${ }^{21}$ Auguste Comte, perintis positivisme, lebih tajam lagi, menjelaskan istilah 'positif' itu dengan membuat beberapa distingsi: antara 'yang nyata' dan 'yang khayal'; 'yang pasti' dan yang meragukan'; 'yang tepat' dan yang kabur'; serta 'yang berguna' dan 'yang sia-sia'. Lihat F. Budi Hardiman, "Positivisme dan Hermeneutik, Suatu Usaha untuk Menyelamatkan Subjek” dalam Basis, Maret 1991

${ }^{22}$ Uraian lebih luas lihat buku penulis, Filsafat Ilmu, Kajian atas Asumsi dasar, Paradigma dan Kerangka Dasar Ilmu Pengetahuan, (Yogyakarta: Belukar Budaya, 2003). 
alam, ilmu-ilmu sosial bersifat bebas-nilai (value-free $)^{23}$

Beberapa prinsip ini memberikan andil besar bagi tereliminasinya sistem pengetahuan lain dan sistem kebenaran lain yang berada di luar jangkauan norma-norma ilmiah itu, seperti metafisika, seni, tradisi dan lebih-lebih agama. Konsekuensinya, jika ingin disebut ilmiah, maka metafisika/ seni, tradisi dan termasuk agama harus mengikuti patok-patok ilmiah secara rigid sebagaimana sains. Di sini derajat sains menjadi lebih tinggi dari segalanya. Inilah yang disebut totalitarianisme in the new fashion.

Posisi Rolston di sini, ingin menjelaskan bahwa sebagaimana agama, sains juga bersifat subjektif atau setidaknya tidak bisa dikatakan benar-benar objektif. Pun juga agama sekalipun memang subjektif, tetap membutuhkan penjelasan yang objektif, atau setidaknya intersubjektif.

Menurut Rolston, sains dan agama, keduanya ada, karena ada proses di dalam diri manusia. Teori dan fakta memang dalam beberapa tingkat merupakan pengetahuan objektif, mewakili dunia nyata, tetapi tidak dapat dielakkan bahwa keduanya adalah pengetahuan subjektif, karena informasi yang diperoleh itu diproses oleh subjek-subjek manusia. Subjek tahu tidak pernah lebih mengetahui daripada yang diketahui. Karena "mengetahui" adalah sebuah hubungan.

Seperti agama, sains dapat dikomunikasikan hanya kepada mereka yang dipersiapkan secara subyektif, yaitu yang mau dan dapat menerima pernyataannya. Sains hanya dihargai oleh mereka yang menghargainya, dan hal ini memerlukan sebuah hubungan dan pendidikan komunitas yang terdidik. Sains memiliki logikanya, bahkan seringkali logikanya itu sangat ketat, tetapi logika tersebut tidak mungkin ada tanpa studi terus-menerus, interaksi kritis, dan ini jelas bernilai, bukan bebas nilai, baik secara logis, psikologis maupun sosiologis. ${ }^{24}$

Jika selama ini ada dugaan bahwa sains harus sepenuhnya

${ }^{23}$ Lihat A. Giddens (ed.). Positivism and Sociology, (London: Heinemann, 1975), h. 34 .

${ }^{24}$ Rolston, Science..., h. 26. 
netral berlawanan dengan agama yang mengandung keterlibatan, tampaknya dugaan harus dirubah dengan melihat lebih jauh berbagai elemen yang terkait dengan keduanya. Kedua bidang itu memang dapat dibedakan pada poin-poin sangat penting, dengan menggunakan paradigma pentingnya, logika khususnya dan keekstremannya. Tetapi pada poin-poin menengah dan dalam nasionalitasnya, pokok perbedaan ini ternyata dapat disamakan, meskipun jelas ada beberapa sisa perbedaan yang tidak dapat disamakan. Ilmu alam membahas dimensi pengalaman yang dapat digolongkan sebagai empiris, sedangkan agama, di luar dunia fenomenal, membahas lebih jauh sebuah dimensi yang digolongkan sebagai eksistensial, moral, spiritual. Ilmu alam dapat memperlakukan segala sesuatu sebagai objek, sementara agama harus memperhitungkan juga subjektivitas yang ada. ${ }^{25}$

Selanjutnya Rolston mengutip Einstein yang mengatakan berkata bahwa "ilmu pengetahuan dikendalikan oleh "nafsu" sama seperti pencarian-pencarian humanistik". Nafsu ini seharusnya meningkatkan kapasitas pendapat bukan menguranginya. Nafsu pada tingkat keterlibatan inilah yang dikembangkan dari mereka yang terlibat pada pekerjaan terapan untuk kesejahteraan manusia. Semua yang baik begitu mencintai disiplin ilmunya sebagaimana mereka membenci kesalahan-kesalahan di dalamnya, terutama yang diperbesar oleh bias partisan. ${ }^{26}$ Maka ilmuwan dan ahli teologi sama-sama mencari apa yang disebut dengan tujuan universal, sebuah pengesampingan kepentingan pribadi untuk memajukan penemuan kebenaran publik yang terfokus pada kebenaran umum dan kebenaran untuk semua orang.

\section{E. Endingnya Juga Sama-sama "Makna"}

Isu keempat yang coba diangkat Rolston adalah soal struktur logis pada sains dan agama. Pandangan tradisional selama ini, menunjukkan bahwa sains mengembangkan logika kausalitas, sementara agama mengembangkan logika "makna”. Logika kausal menyokong logika komputasional, baik induktif ataupun deduktif, sedangkan logika makna melibatkan sebuah

\footnotetext{
${ }^{25}$ Ibid., h. 29.

${ }^{26}$ Ibid., h. 24
} 
kejelasan yang lebih holistik. Kausalitas masuk ke dalam jaringan linier, yang sering kali memperkenankan pengukuran hubungan teoritis, terukur dengan angka seperti panjang gelombang dan korelasi stimulus respon, meskipun kita seharusnya tidak melupakan bahwa angka tersebut, yang kelihatan sangat akurat dan objektif, tetapi memiliki batas kesalahannya. ${ }^{27}$

Kausalitas terkait tatanan fakta atau peristiwa dalam realitas, sementara makna merupakan tafsiran dari realitas dan merupakan konstruksi mental. Persoalan epistemologis yang muncul adalah benarkah kausalitas itu tatanan fakta atau peristiwa dalam realitas? Para penganut paradigma cartesian sudah tentu membenarkannya. Tetapi kalangan empirisis sejak David Hume menyangkalnya. Bagi empirisis, peristiwa yang terjadi setelah peristiwa yang lain tidak bisa dikatakan ada hukum kausalitas/ seperti hujan setelah cuaca mendung. Dua peristiwa itu hanyalah berurutan bukan yang satu menyebabkan yang lain, atau sebaliknya yang satu diakibatkan yang lain.

Adalah Immanuel Kant yang memberi penjelasan lain. Seperti diketahui, Kant berhasil mendamaikan dua paham di atas. Menurut Kant, manusia memiliki dua potensi yang disebut apriori sebagai derivasi dari rasio dan aposteriori sebagai derivasi dari pengalaman inderawi. Sintesis dari kedua potensi itu menjadikan manusia "mengetahui". Apriori bertindak sebagai bentuk (form) dan bersifat aktif mengkonstruk, sedang aposteriori berbentuk bahan (matter) dan bersifat pasif (tidak akan berubah menjadi bahan pengetahuan kalau tidak dikonstruk oleh apriori). Menurut Kant apriori terdiri dari kategori-kategori, (Kategorie), yakni ideide bawaan yang mempuyai fungsi epistemologis dalam diri manusia. Ada 12 kategori yang membuat manusia mengetahui, yaitu kuantitas (kesatuan, kejamukan, keutuhan); kualitas (realitas, negasi, dan pembatasan); relasi (substansi dan aksidensi, sebab-akibat [kausalitas], interaksi); modalitas (mungkin/mustahil, adaltiada, keperluan/kebetulan). ${ }^{28}$

Apa artinya ini? Artinya adalah bahwa kausalitas sebenarnya

${ }^{27}$ Ibid., h. 38-39.

${ }^{28}$ Emmanuel Kant, Critiijue of Pure HAL.enwn Translated by JMD. Meikiejohn, (New York: Prometheus Books, 1990), h. 61. 
juga konstruksi subjektif dari manusia selaku subjek tahu. Dengan mengikuti Kant, Rolston juga mengakui bahwa kausalitas dan "makna" tak lain merupakan komposisi pikiran. ${ }^{29}$ Ada beberapa godaan untuk mengatakan bahwa hubungan kausal itu "benarbenar ada”, teramati, objektif/ sedangkan makna itu ditemukan, subyektif, hanya "di dalam diri kita”. Yang jelas, bahwa hubunganhubungan kausal tampak setelah kita mengetahui sesuai dengan struktur dan konstruksi mental kita/ sementara makna muncul pada subjek yang secara eksperiensial berhubungan dengan dunianya.

\section{F. Penutup}

Secara metodologis, antara sains dan agama sebenarnya dapat saling mengisi. Teori dalam sains dan teologi dalam agama ternyata dapat bertemu pada wilayah metodologi untuk tidak mengatakan pada wilayah filsafat keilmuannya. Empat isu yang diangkat Rolston menunjukkan dengan jelas bahwa logika hipotetis-deduktis dan peran paradigma yang sebenarnya khas bagi sains, ternyata juga terjadi pada agama. Sebaliknya "keterlibatan" atau subjektivitas dan logika "makna" yang khas bagi agama/ ternyata juga terjadi pada sains. []

\section{Daftar Pustaka}

Basis, Maret 1991. Salim, Agus, Teori-Teori dan Paradigma Penelitian Sosial, Yogyakarta: Tiara Wacana, 2001.

Edward, Paul, (ed.). The Encyclopedia Phylosophy, vol. VI.

Faucoult, Michel, Diciplin and Punish: Tfie Brith of Prison, trans. Alan Sheridan, New York: Peregrine, 1979.

Giddens, Antony, (ed.), Positivism and Sociology, London: Heinemann, 1975.

Hanfling, Oswald, (ed.), Essential Reading in Logical Positivism, Oxford: Basil Blackwell, 1981. Jurnal Driyarkara, Tahun XIX, no. 2.

Kant, Emmanuel, Critiijue of Pure, Translated by JMD. Meikiejohn, New York: Prometheus Books, 1990.

${ }^{29}$ Rolston, Science..., h. 36 
Kuhn, Thomas S., The Structure of Scientific Revolution, Chicago: The University of 50 Press, 1970. Lyotard, The Postmodern Condition, A Report and Knowledge, Manchester: Manchester University Press, 1984.

Muslih, Mohammad, Filsafat Ilmu, Kajian atas Asumsi Dasar, Paradigma dan Kerangka Dasar Ilmu Pengetahuan, (Yogyakarta: Belukar Budaya), 2003.

Popper, Karl R. , Conjuctures and Refutations: The Growth litific Knowledge, ed. Revisi, cet. V, London: Routledge, 1974.

Rolston, Holmes, Science and Religion: a Critical Survey, USA: Templeton Foundation Press, 2006. 